\title{
BIBECHANA
}

A Multidisciplinary Journal of Science, Technology and Mathematics ISSN 2091-0762 (Print), 2382-5340 (Online)

Journal homepage: http://nepjol.info/index.php/BIBECHANA

Publisher: Research Council of Science and Technology, Biratnagar, Nepal

\section{Food and feeding habit of Tor putitora of Mahakali River, Nepal}

\author{
Vinod Kumar Mahaseth \\ Department of Zoology, MMAM Campus, Tribhuvan University, Biratnagar, Nepal \\ Email: vkmahaseth1962@gmail.com \\ Article history: Received 07 November, 2015; Accepted 29 November, 2015 \\ DOI: http://dx.doi.org/10.3126/bibechana.v13i0.13983
}

\section{Abstract}

T.putitora is a sight feeder and can be categorized as column feeder, which at some stage resorts to bottom feeding as well. Depending upon the availability of food, the fish consumes a wide spectrum of dietary items varying from microscopic organisms and macrophytes to large number of insects and even small fishes.

The feeding activities of $T$. putitora appeared to be good during pre-spawning (pre-monsoon) and postspawning season while poor during monsoon or spawning season, which is directly related to the availability of food and maturation of gonads. The estimation of GSI (Gastro-somatic Index) also supported this fact.

CRCOST: All rights reserved.

Keywords: Mahakali river; Tor putitora; Gut.

\section{Introduction:}

Tor putitora which is commonly known as Mahseer or Sahar or Golden Mahseer. In Nepal Mahseer is known as 'Sahar', which means a big fish. It has large scales. It is a superior game fish. Live adult Mahseer is olive green at the top of the head and back. Its lateral line is generally silvery golden. The scales on the lateral line are marked with dark colour at their bases. The fins are generally yellow and rimmed with orange red. The lips of the adult mahseer are thick and are beset with horny tubercles. Its barbels are quite short. Only four barbels are present ones being the maxillary longer than the rostral ones. Feeding is one of the most important functions of an organism. The basic functions of an organism, like growth, development, reproduction all take place at the expense of the energy, which enters the organism in the form of its food. Feeding activity influences the growth and productivity of fishes. Therefore, the study of food and feeding habits of a fish is very important.

Important contributions on food and feeding habits of the different fishes have been made by Hynes [1], Alikunhi [2], Das and Moitra [3], Menon and Chacko [4], Vashist [5], George [6], Kamal [7], Agrawal and Tyagi [8] Jan and Das [9], Majkowski and Waiwood [10], Bahuguna and Singh [11]. Some work on food and feeding habits has also been done by Pathani [12], Nautiyal [13], Sundar et al.[14], Sharma [15], DasGupta [16], Bhanja et al. [17], Hossain et al. [18], Basade and Kohli [19], Joadder and Hossain [20], 
Dadebo [21], Shinkafi et al. [22], Manon and Hossain [23], Kanwal and Pathani [24], Omondi et al.[25], and Sharma et al.[26].

But there is no relevant literature on food and feeding habits of Mahseer inhabiting Mahakali river. The present investigation is the first attempt to study the feeding habit of Mahseer in its habitat. During the study period qualitative and quantitative food analysis, seasonal variations in the food items, gastrosomatic index (GSI), feeding intensity and relative length of the gut (RLG) of Mahseer were observed.

\section{Study Area}

Mahakali river originates from Indo-Nepalese glaciers, Milan glacier of India and Lipu-lekh of Nepal. The river leaves the mountains near Tanakpur and is now known as Sarada in India. Later, it reaches Sharada barrage, where it is considerably wider. Mahakali then enters into Nepal at Chandani and flows through Nepal upto Dodhara, after which it enters into Indian territory, finally confluencing with the Ghaghara.

The present studies were conducted at the Chandani and Dodhara V. D. C. (Village Development Committee). They are the V. D. C. of Kanchanpur district near the bank of Mahakali river. The study area lies between longitude $80^{0} 25^{\prime}$ East and latitude $28^{0} 35^{\prime}$ North.

Four stations (A, B, C and D) were selected. First station 'A' is an upper station, which is near at Purnagiri temple of Syavle Bajar. Second station 'B' is 4 kilometres from station A. Third station 'C', which is 4 kilometres from station B. Fourth station ' $\mathrm{D}$ ' is a lower station, which is 4 kilometres from station $\mathrm{C}$.

\section{Materials and Methods}

The present study was carried out for a period of two years. The period from September 2003 to August 2005 was used to collect the fishes.

\section{Gut Analysis:}

The samples were collected fortnightly; total length was recorded up to the nearest centimetre and the weight up to gram. The gut of each fish was removed, the weight of the gut and gut contents were also recorded and preserved in $5 \%$ formaldehyde for analysis.

The gut content of each fish was transferred in to a petridish and examined under a microscope. Each food item was sorted out and identified. The food item per fish was examined by the frequency of occurrence method and point's method of Hynes [1].

\section{Qualitative analysis and food volume:}

In this method food items were sorted out and were identified up to genus level only. Food volume was measured in partially filled graduated cylinder. The entire gut content was kept in 10-125 ml graduated measuring cylinder. The settling was done for 24 hours, after which the volume was read and recorded for each fish, in the catches of each fortnight. The fullness of stomach was classified as very full, $3 / 4$ full, $1 / 2$ full, $1 / 4$ full and empty. The points were awarded for each category as $20,15,10,5$ and 0 , respectively. The resultant fullness index was based on mean number of points, which was calculated by the total number of the awarded points divided by the number of stomachs examined in each fortnight. This 
depends on eye estimation of distension of intestinal bulb confirmed by ratio of the capacity of the intestinal bulb to total food.

\section{Quantitative analysis}

Quantitative study of fish food in each intestinal bulb was measured by Hynes [1] method. For quantitative accuracy only the intestinal bulb content was considered as gut content. The Sedgwick Rafter method was used for counting each food item and was given a point, according to their size as seen in Sedgwick Rafter slide, using a research microscope. GSI (Gastro somatic index) was calculated by following formula:

$$
\begin{aligned}
\text { GSI }= & \frac{\text { Total weight of the alimentary canal of fish }}{\text { Total weight of fish }} \times 100 \\
\text { RLG }= & \frac{\text { Length of entire alimentary canal }}{\text { Length of fish in fresh condition }}
\end{aligned}
$$

\section{Results}

\section{Qualitative Monthly Fluctuation in Food Items}

The identified food items are listed in Tabl 1. The identified food items were grouped under 12 categories, Chlorophyceae, Cyanophyceae, Bacillariophyceae, Xanthophyceae, Protozoa, Rotifera, Crustacea, Fish parts, Insects, unidentified plant matter, unidentified animal matter and sand and debris.The Chlorophyceae, Cyanophyceae, Bacillariophyceae were found throughout the year during entire study period and are considered as preferred food. Xanthophyceae was found only in three months during the first year and two months in second year from the gut of Tor putitora. Protozoan, Rotifers, Crustaceans, Fish parts and Insects were found in low amount in few months of both years (Table $2 \& 3$ ).

\section{Quantitative Monthly Fluctuation in Food Items: \\ Chlorophyceae}

The group Chlorophyceae consisted of Chlorella, Ankistrodesmus, Gonatozygon, Scenedesmus, Mougeotia, Chlamydomonas, Periastrum, Spirogyra, Desmidium, Coelastrum, Cylindocystis, Coefastrum, Dictyosphaerium, Ulothrix and Cladophora.

This group occurred throughout the investigation in the gut of $T$. putitora. During the first year, it varied from a minimum of $12.40 \%$ (September 2003) and maximum of $43.10 \%$ (February 2004). In second year, this alga varied from minimum 19.23 in December 2004 and maximum $39.13 \%$ in the month of May 2005 (Table 4 \& 5).

The important constituents of this alga were Chlorella, Spirogyra, and Gonatozygon. The annual mean percentages of these algae were 28.58 and 25.94 during first and second year, respectively (Table $4 \& 5$ ).

\section{Cyanophyceae}

The maximum contribution of Cyanophyceae was recorded during the month of October $18.62 \%$ and minimum $4.31 \%$ in the month of February during the first year while in second year, the maximum value was recorded $17.47 \%$ in the month of March and minimum $7.24 \%$ in the month of September (Table 4 \& 5). Microcystis was the most prevalent form of this group. The annual mean percentage of this group was 
$11.55 \%$ and $12.54 \%$ during first and second year, respectively (Table $4 \& 5$ ). Cyanophyceae was recorded throughout the study period.

\section{Bacillariophyceae}

Bacillariophyceae was the second most important alga which was found throughout the twenty four months of the study period, in the gut of T. putitora. The percentage value of Bacillariophyceae varied from $5.78 \%$ (June 2004) to $33.61 \%$ (April 2004) during the first year while in second year, it varied from $9.63 \%$ (August 2005) to $32.29 \%$ (February 2005). The important diatoms were Diatoma and Synedra which were found almost throughout the study period. The annual mean percentages of this group were $20.92 \%$ and $22.39 \%$ during first and second year, respectively (Table 4 \& 5).

\section{Xanthophyceae}

This group of alga was rarely found in the gut of $T$. putitora. Xanthophyceae was found only in the months of April, May and July during the first year while in September and January in second year of investigation. Tribonema and Tetraedriella were important forms of this group. The annual mean percentages of this group were 0.84 and $0.24 \%$ during first and second year, respectively (Table $4 \& 5$ ).

\section{Protozoa}

This group of food item was found during several months in the entire study period, but in little amount. The peak of this group was observed in the month of July $6.29 \%$ and February $12.50 \%$ during first and second year, respectively. This group was represented by Paramecium, Spirostomum and Verticella. The annual mean percentages of this group were 2.67 and 3.17 during first and second year, respectively (Table 4 \& 5).

\section{Rotifers}

This group was represented by Keretella, Nothalca, Rotaria, Brachionus, Philodina, Mytilina and Dinobryon but Kiretella was the important form of this group. Rotifers were observed throughout the year during first year while they have absent from January 2005 to March 2005 during the second year. The peak of this group was observed in the month of June (15.70\%) and September (10.14\%) during first and second year, respectively. The annual mean percentages of this group were 8.01 in first and $5.40 \%$ during second year (Table $4 \& 5$ ).

\section{Crustaceans}

Crustaceans were observed in several months, during the period of investigation. Daphnia and Cyclops were main form of this group. The peak of this group were observed in the month of June $(10.74 \%)$ and December $(16.34 \%)$ during the first and second year, respectively. The annual mean percentages of this group were 5.23 and 4.40 during respective year (Table $4 \& 5$ ).

\section{Fish Remains}

Only in the month of September, some parts of fish were observed in the gut of T. putitora, during the first year. In second year of observations, they were found in various months (September. October, January, April, June) while absent in the remaining seven months of the year. The annual mean percentage of fish parts was very low $(0.55 \%)$ during the first year while $2.85 \%$ during the second year (Table 4 \& 5).

\section{Insects}

Some parts of insects were found in the gut of T. putitora in few months (December, January and August) of first year. In second year, they were present in the month of September, December, January, March, 
May and August. The peak of this group was observed in the month of August in both years. The annual mean percentages were 1.27 and 3.57 during first and second years, respectively (Table $4 \& 5$ ).

\section{Unidentified Plant Matter}

This group of food item was observed in decayed or semi decayed state. It was found in appreciable quantities throughout the year during whole study period. Its percentage of occurrence was highest in the month of October $(11.76 \%$ and $10.52 \%)$ during both years of investigation. The lowest value of this group was $3.14 \%$ in the month of July 2004 and $1.94 \%$ in the month of March 2005 during respective years. The annual mean percentages were observed 6.41 and 6.33 during first and second year, respectively (Table $4 \& 5$ ).

\section{Unidentified Animal Matter}

This group of food item was observed in a decayed or semi decayed state like unidentified plant matter. It was also found throughout the year during investigation. Its percentage of occurrence was highest in the month of February (8.62) and lowest in the month of April (3.36) during the first year while in second year, the highest value was observed in the month of May (6.52\%) and lowest in the month of April (1.98 $\%$ ). The annual mean percentages were 5.72 and 3.62 during first and second years of observations (Table $4 \& 5)$.

\section{Sand and Debris}

The sand and debris were observed within the gut content throughout the year. Their percentage varied from 3.42 (January 2004) to 18.69 (August 2004) and 2.98 (January 2005) to 26.50 (August 2005) during the first and second years of investigation, respectively (Table $4 \& 5$ ). The peak was observed in the month of August (monsoon) during whole study period, when turbidity was as its peak.

\section{Gastro-Somatic Index}

The gastro-somatic index (GSI) is a relationship between weight of alimentary canal and weight of fish, which helps in determining the feeding condition in different months and seasons. The average gastrosomatic index of T. putitora ranged from 1.33 to 4.59 during the first year while 1.65 to 4.73 in second year of the study. The peak of gastro-somatic index was observed during the pre monsoon season (April 2004 and March 2005) when the plankton was as its peak during the entire study period (Fig 1).

Gastro-somatic index was as high as 3.44 and 3.08 during post-spawning season in the month of November and December during the first year of study. In the second year of observation, the gastro somatic index was as high as 3.69 and 3.90 in the same month during post- spawning season like first year (Fig 1). The general picture emerges that voracious feeding takes place during post spawning season and whenever plenty of food items were available in the river.

\section{Relative Length of Gut}

The length of intestine varies from fish to fish, but for a particular species, it has a definite relation with length of fish which helps to determine the feeding habits of the fish species. Relative length of gut (RLG) differs in different stages of life history of fish. The relative length of gut values of $T$. putitora varied from 1.48 to 2.18 during the first year while in second year its value ranged between 1.32 to 2.07 (Fig 2). The maximum values were obtained in the months of January (2004) and May (2005) during the first and second year of study, respectively. The minimum values were obtained in the months of May (2004) and July (2005) during the respective years of study period. The quantitative food and study of the 
alimentary canal show, this fish to be more of a herbivore than an omnivore. Therefore, T. putitora has been categorized to be of herbi-omnivorous nature.

\section{Discussion}

Nikolsky [27] classified the food of fish into four categories basic, secondary, accidental and obligatory food. The basic food of $T$. putitora constitutes phytoplankton specially Chlorophyceae (28.58\% during first year and $25.94 \%$ in second year), Bacillariophyceae (20.92\% in first year and $22.39 \%$ in second year), Cyanophyceae (11.55 and $12.54 \%$ during first and second year, respectively).

The Rotifers, Protozoans, Crustaceans and Insects comprise the secondary food, which were found frequently in the gut but in small amounts. Fish parts and Xanthophyceae group of phytoplankton were observed as accidental food in the gut of $T$. putitora. The sand and debris were also present throughout the year but in small amount.

The food and feeding habits and adaptations of the gut have been worked out by many authors. It is a fact that the vegetable matter requires more time for digestion, hence herbivorous fishes have higher RLG (Relative length of gut) value than omnivorous fishes.

In the present study, two years mean of RLG value of $T$. putitora was 1.73 . On this basis, $T$. putitora may be kept in the category of herbi - omnivorous fishes. This observation is in conformation with the observations made by Das and Pathani [28], who have considered T. putitora to be a herbi-omnivore on the basis of RLG value, percentage of food items and position of the bile duct. The herbi-omnivorous nature of $T$. putitora has been considered to be a peculiar example of evolutionary transition from herbivorous to omnivorous nature (Das and Pathani, [28]). However, the result of present study differs from the opinion of Badola and Singh [29], who have categorized T. putitora to be a carni - omnivorous fish.

In the present study, the maximum feeding intensity in $T$. putitora was recorded during pre-monsoon as well as pre-spawning season (April 2004 and March 2005), during which the planktons were plenty in number. During the post spawning season also (November and December), the feeding intensity was high (3.44, 3.08 and 3.69, 3.90 during first and second year, respectively). High feeding intensity during prespawning is due to maturation and enlargement of the gonads while during post-spawning it may be due to spent and starved condition of the fishes. Feeding intensity is correlated with the post- spawning period and the availability of food in the river Mahakali, which confirms the view of Malhotra [30], Jyoti and Malhotra [31], and Jyoti [32].

During monsoon season (July and August) shortage of food items in the Mahakali river and the abdomen being filled with mature gonads may be the reason for lowering of feeding intensity. In general, the GSI is maximum during the post spawning period when plenty of food items are available and minimum during the breeding season when food materials become less.

Therefore, it may be concluded that $T$. putitora of Mahakali river feeds voraciously during pre-spawning when plenty of food items are available followed by the post-spawning season when its abdomen becomes empty due to spent phase. 


\title{
Acknowledgements
}

Thanks are due to the campus chief of S.N.Science Campus, Mahendranagar for providing the necessary facilities to present work. The author is thankful also to Dr. (Mrs.) Manju Lata Bisht, Department of zoology, D.S.B. Campus, Kumaun University, Nainital for her valuable guidance.

Table 1: List of Food Items Found in the Gut of T. putitora during 2003/05.

\author{
Species \\ Chlorophyce \\ Chlorella $\mathrm{Sp}$. \\ Gyrosigma Sp. \\ Ankistrodesmus Sp. \\ Tabellaria Sp. \\ Gonatozygon Sp. \\ Navicula Sp. \\ Scenedesmus Sp. \\ Fragilaria Sp. \\ Mougeotia Sp. \\ Cymbella Sp. \\ Chlamydomonas Sp. \\ Xanthophyceae \\ Pediastrum Sp. \\ Tribonema Sp. \\ Spirogyra Sp. \\ Tetraedriella Sp. \\ Desmidium Sp. \\ Chrysoamphitrema Sp. \\ Coelastrum Sp. \\ Protozoa \\ Cylindrocystis Sp. \\ Paramecium Sp. \\ Dictyosphaerium Sp. \\ Spirostomum Sp. \\ Ulothrix Sp. \\ Vorticella Sp. \\ Cladophora Sp. \\ Rotifera \\ Cyanophyceae \\ Keratella Sp. \\ Microcystis Sp. \\ Notholca Sp. \\ Chroococcus Sp. \\ Rotaria Sp. \\ Aphanizomenon Sp. \\ Brachionus Sp. \\ Spirulina Sp. \\ Philodina Sp. \\ Anabaena Sp. \\ Mytilina Sp. \\ Bacillariophyceae \\ Crustacea \\ Diatoma $\mathrm{Sp}$. \\ Daphnia Sp. \\ Asterionella Sp. \\ Cyclops Sp. \\ Synedra Sp. \\ Chirocephalus Sp. \\ Gomphonema Sp. \\ Orchestia Sp. \\ Fish parts \\ Insects \\ Unidentified plant matter \\ Unidentified animal matter \\ Sand and debris
}


Vinod Kumar Mahaseth / BIBECHANA 13 (2016) 121-131: RCOST p. 128 (Online Publication: Dec., 2015)

Table 2: Monthly average no. of different food items (Groups) in gut of T.putitora during 2003/04.

\begin{tabular}{|c|l|l|l|l|l|l|l|l|l|l|l|l|l|}
\hline \multicolumn{1}{|c|}{ Month } & Sep & Oct. & Nov. & Dec. & Jan. & Feb. & Mar. & Apr. & May & Jun. & Jul. & Aug. & Total \\
\hline Food groups & - & & & & & & & & & & & & \\
\hline Chlorophyceae & 15 & 22 & 39 & 47 & 49 & 50 & 33 & 35 & 27 & 29 & 32 & 27 & 405 \\
\hline Cyanophyceae & 19 & 19 & 14 & 08 & 13 & 05 & 11 & 12 & 13 & 17 & 15 & 15 & 161 \\
\hline Bacillariophycea & 30 & 14 & 21 & 25 & 43 & 26 & 36 & 40 & 23 & 07 & 21 & 12 & 298 \\
\hline Xanthophyceae & - & - & - & - & - & - & - & 05 & 03 & - & 04 & - & 012 \\
\hline Protozoa & 03 & 04 & 02 & - & - & 04 & - & - & 03 & 07 & 08 & 06 & 037 \\
\hline Rotifera & 11 & 08 & 06 & 05 & 06 & 08 & 10 & 12 & 08 & 19 & 09 & 10 & 112 \\
\hline Crustacea & 07 & 08 & 06 & 11 & 09 & - & - & - & 10 & 13 & 11 & - & 075 \\
\hline Fish parts & 08 & - & - & - & - & - & - & - & - & - & - & - & 008 \\
\hline Insect & - & - & - & 04 & 08 & - & - & - & - & - & - & 07 & 019 \\
\hline $\begin{array}{c}\text { Unidentified } \\
\text { plant matter }\end{array}$ & 10 & 12 & 09 & 08 & 07 & 08 & 07 & 05 & 06 & 07 & 04 & 06 & 089 \\
\hline $\begin{array}{c}\text { Unidentified } \\
\text { animal matter }\end{array}$ & 08 & 07 & 08 & 09 & 06 & 10 & 06 & 04 & 07 & 06 & 05 & 04 & 080 \\
\hline Sand \& debris & 10 & 08 & 07 & 06 & 05 & 05 & 06 & 06 & 07 & 16 & 18 & 20 & 114 \\
\hline Total & 121 & 102 & 112 & 123 & 146 & 116 & 109 & 119 & 107 & 121 & 127 & 107 & 1410 \\
\hline
\end{tabular}

Table 3: Monthly Average no. of different food items (Groups) in gut of T.putitora during 2004/05.

\begin{tabular}{|c|l|l|l|l|l|l|l|l|l|l|l|l|l|}
\hline $\begin{array}{c}\text { Month } \\
\text { Food groups }\end{array}$ & Sep. & Oct. & Nov. & Dec. & Jan. & Feb. & Mar. & Apr. & May & Jun. & Jul. & Aug. & Total \\
\hline Chlorophyceae & 32 & 22 & 28 & 20 & 35 & 26 & 33 & 29 & 36 & 23 & 21 & 16 & 321 \\
\hline $\begin{array}{c}\text { Cyanophyceae } \\
10\end{array}$ & 08 & 13 & 12 & 21 & 15 & 18 & 14 & 08 & 09 & 13 & 14 & 155 \\
\hline Bacillariophyceae & 32 & 21 & 23 & 27 & 31 & 31 & 29 & 26 & 14 & 21 & 18 & 08 & 281 \\
\hline Xanthophyceae & 02 & - & - & - & 02 & - & - & - & - & - & - & - & 004 \\
\hline Protozoa & 02 & 03 & 02 & - & - & 12 & 03 & - & - & - & 12 & 04 & 038 \\
\hline Rotifera & 14 & 09 & 09 & 02 & - & - & - & 08 & 09 & 02 & 09 & 05 & 067 \\
\hline Crustacea & 08 & 07 & 06 & 17 & 13 & - & - & - & 02 & - & 06 & - & 059 \\
\hline Fish parts & 07 & 06 & - & - & 08 & - & - & 09 & - & 07 & - & - & 037 \\
\hline Insect & 07 & - & - & 08 & 10 & - & 08 & - & 06 & - & - & 07 & 046 \\
\hline $\begin{array}{c}\text { Unidentified plant } \\
\text { matter }\end{array}$ & 08 & 10 & 09 & 07 & 05 & 03 & 02 & 07 & 06 & 09 & 06 & 05 & 077 \\
\hline $\begin{array}{c}\text { Unidentified animal } \\
\text { matter }\end{array}$ & 04 & 03 & 05 & 06 & 05 & 04 & 03 & 02 & 06 & 02 & 03 & 02 & 045 \\
\hline \begin{tabular}{c} 
Sand \& debris \\
\hline Total
\end{tabular} & 12 & 06 & 07 & 05 & 04 & 05 & 07 & 06 & 05 & 15 & 18 & 22 & 112 \\
\hline
\end{tabular}


Vinod Kumar Mahaseth / BIBECHANA 13 (2016) 121-131: RCOST p. 129 (Online Publication: Dec., 2015)

Table 4: Monthly average percentage of different food items (groups) in gut of T.putitora during 2003/04.

\begin{tabular}{|c|c|c|c|c|c|c|c|c|c|c|c|c|c|}
\hline Food groups & Sep. & Oct. & Nov. & Dec. & Jan. & Feb. & Mar. & Apr. & May & Jun. & Jul. & Aug. & Average \\
\hline Chlorophyceae & 12.40 & 21.56 & 34.82 & 38.21 & 33.56 & 43.10 & 30.27 & 29.41 & 25.23 & 23.96 & 25.19 & 25.23 & 28.58 \\
\hline Cyanophyceae & 15.70 & 18.62 & 12.50 & 6.50 & 8.90 & 4.31 & 10.09 & 10.08 & 12.14 & 14.04 & 11.81 & 14.01 & 11.55 \\
\hline Bacillariophycea & 24.79 & 13.72 & 18.75 & 20.32 & 29.45 & 22.41 & 33.02 & 33.61 & 21.50 & 5.78 & 16.53 & 11.21 & 20.92 \\
\hline Xanthophyceae & - & - & - & - & - & - & - & 4.20 & 2.80 & - & 3.14 & - & 0.84 \\
\hline Protozoa & 2.47 & 3.92 & 1.78 & - & - & 3.45 & - & - & 2.80 & 5.78 & 6.29 & 5.60 & 2.67 \\
\hline Rotifera & 9.09 & 7.84 & 5.35 & 4.06 & 4.10 & 6.89 & 9.17 & 10.08 & 7.47 & 15.70 & 7.08 & 9.34 & 8.01 \\
\hline Crustacea & 5.78 & 7.84 & 5.35 & 8.94 & 6.16 & - & - & - & 9.34 & 10.74 & 8.66 & - & 5.23 \\
\hline Fish parts & 6.61 & - & - & - & - & - & - & - & - & - & - & - & 0.55 \\
\hline Insect & - & - & - & 3.25 & 5.47 & - & - & - & - & - & - & 6.54 & 1.27 \\
\hline $\begin{array}{l}\text { Unidentified } \\
\text { plant } \\
\text { Matter }\end{array}$ & 8.26 & 11.76 & 8.03 & 6.50 & 4.79 & 6.89 & 6.42 & 4.20 & 5.60 & 5.78 & 3.14 & 5.60 & 6.41 \\
\hline $\begin{array}{c}\text { Unidentified } \\
\text { animal } \\
\text { matter }\end{array}$ & 6.61 & 6.86 & 7.14 & 7.31 & 4.10 & 8.62 & 5.50 & 3.36 & 6.54 & 4.95 & 3.93 & 3.73 & 5.72 \\
\hline $\begin{array}{l}\text { Sand \& } \\
\text { debris }\end{array}$ & 8.26 & 7.84 & 6.25 & 4.87 & 3.42 & 4.31 & 5.50 & 5.04 & 6.54 & 13.22 & 14.17 & 18.69 & 8.17 \\
\hline
\end{tabular}


Vinod Kumar Mahaseth / BIBECHANA 13 (2016) 121-131: RCOST p. 130 (Online Publication: Dec., 2015)

Table 5: Monthly average percentage of different food items (groups) in gut of T.putitora during 2004/05.

\begin{tabular}{|c|c|c|c|c|c|c|c|c|c|c|c|c|c|}
\hline Food groups & Sep. & Oct. & Nov. & Dec. & Jan. & Feb. & Mar. & Apr. & May & Jun. & Jul. & Aug. & Average \\
\hline Chlorophyceae & 23.18 & 23.15 & 27.45 & 19.23 & 26.11 & 27.08 & 32.03 & 28.71 & 39.13 & 26.13 & 19.81 & 19.27 & 25.94 \\
\hline Cyanophyceae & 7.24 & 8.42 & 12.74 & 11.53 & 15.67 & 15.62 & 17.47 & 13.86 & 8.70 & 10.22 & 12.26 & 16.86 & 12.54 \\
\hline Bacillariophyceae & 23.18 & 22.10 & 22.54 & 25.96 & 23.13 & 32.29 & 28.15 & 25.74 & 15.21 & 23.86 & 16.98 & 9.63 & 22.39 \\
\hline Xanthophyceae & 1.45 & - & - & - & 1.49 & - & - & - & - & - & - & - & 0.24 \\
\hline Protozoa & 1.45 & 3.15 & 1.96 & - & - & 12.50 & 2.91 & - & - & - & 11.32 & 4.81 & 3.17 \\
\hline Rotifera & 10.14 & 9.47 & 8.82 & 1.92 & - & - & - & 7.92 & 9.78 & 2.27 & 8.49 & 6.02 & 5.40 \\
\hline Crustacea & 5.79 & 7.36 & 5.88 & 16.34 & 9.70 & - & - & - & 2.17 & - & 5.66 & - & 4.40 \\
\hline Fish parts & 5.07 & 6.31 & - & - & 5.97 & - & - & 8.91 & - & 7.95 & - & - & 2.85 \\
\hline Insect & 5.07 & - & - & 7.69 & 7.46 & - & 7.76 & - & 6.52 & - & - & 8.43 & 3.57 \\
\hline $\begin{array}{l}\text { Unidentified } \\
\text { plant } \\
\text { Matter }\end{array}$ & 5.79 & 10.52 & 8.82 & 6.73 & 3.73 & 3.12 & 1.94 & 6.93 & 6.52 & 10.22 & 5.66 & 6.02 & 6.33 \\
\hline $\begin{array}{l}\text { Unidentified } \\
\text { animal } \\
\text { matter }\end{array}$ & 2.89 & 3.15 & 4.90 & 5.76 & 3.73 & 4.16 & 2.91 & 1.98 & 6.52 & 2.27 & 2.83 & 2.40 & 3.62 \\
\hline Sand \& debris & 8.69 & 6.31 & 6.86 & 4.80 & 2.98 & 5.20 & 6.79 & 5.94 & 5.43 & 17.04 & 16.98 & 26.50 & 9.79 \\
\hline
\end{tabular}

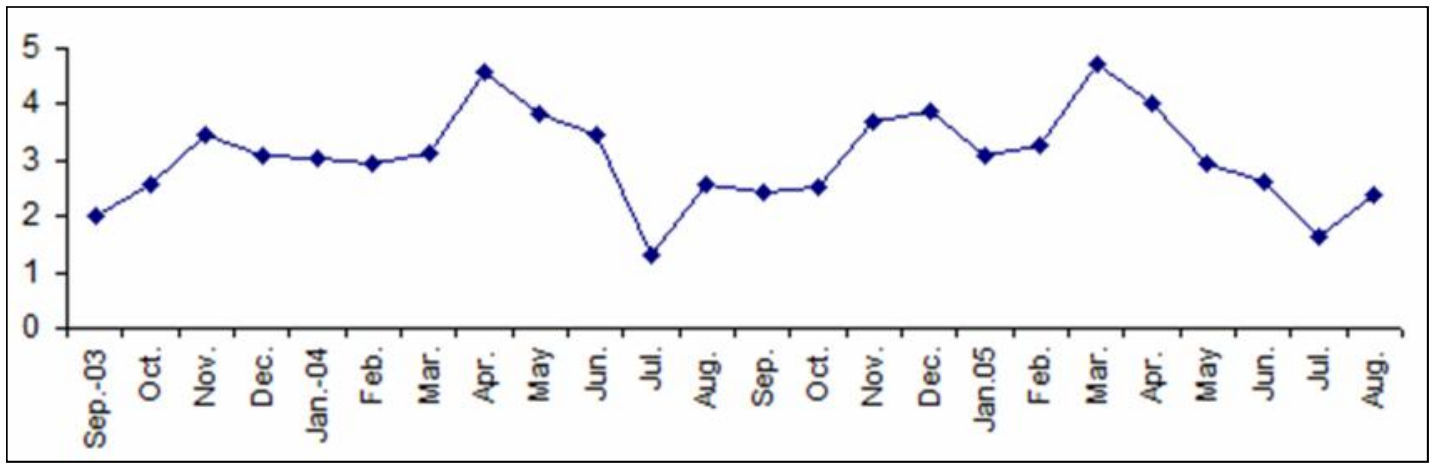

Fig. 1: Gastro-somatic index of T. putitor. 


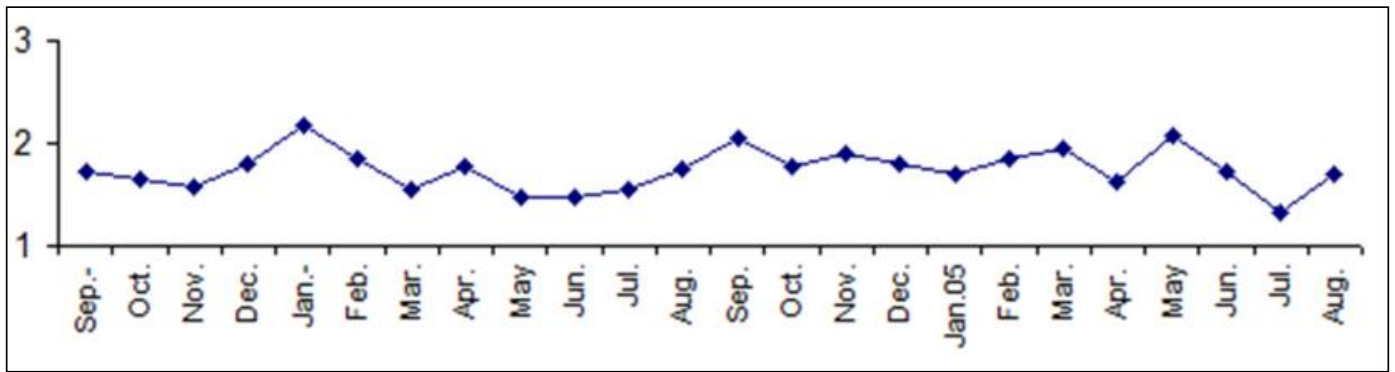

Fig. 2: Relative length of gut of T. putitora.

\section{References}

[1] H. B. N. Hynes, J. Anim. Ecol., 19 (1950) 36.

[2] K. H. Alikunhi, J. Zool. Soc. India, 4 (1952) 77.

[3] S. M. Das and S. K. Moitra, Proc. Nat. Acad. Sci. India, 25 (1955)1.

[4] M. D. Menon and P. I. Chacko, Proc. Indo-Pacif. Fish. Coun., 6 (1955) 182.

[5] H. S. Vasisht, Res. Bull. Punjab., 10 (1959) 65.

[6] M. G. George, Curr. Sci. 32 (1963) 79.

[7] M. Y. Kamal, Indian J. Fish., 14 (1967) 24.

[8] V. P. Agrawal and A. P. Tyagi, Jour. Rec., (Sc) 18 (1969) 15.

[9] N. A. Jan and S. M. Das, Ichthyologica., X (1970) 21.

[10] J. Majkowski and K. G. Waiwood, J. Fish. and Aquatic Sciences, 38 (1981) 1189.

[11] S. N. Bahuguna and H. R. Singh, Ind. J. Animal Sciences, 51 (1981) 964.

[12] S. S. Pathani, Himalayn Research and Development, 1 (1982) 161.

[13] P. Nautiyal, J. Bombay, Natural Hist. Society, 81 (1984) 642.

[14] S. Sunder, K. Kumar and H. S. Raina, Indian J. Fish., 31 (1984) 90.

[15] R. C. Sharma, Matsya, 12-13(1986 - 87) 93.

[16] M. DasGupta, Indian Journal of Fisheries, 38 (1991) 212.

[17] S. K. Bhanja, K. D. Joshi, and Joshi, B. C. Joshi, J. Aqua., 9 (2001)53.

[18] M. A. Hossain, N. Hasan, A. K. M. A. Shah and M. G. Hussain, Asian Fisheries Science, 15(2002) 203.

[19] Y. Basade and M. P. S. Kohli, Indian J. Fish, 51 (2004) 123.

[20] A.R. Joadder and M.D. Hossain, J. Sci. Foundation, 6 (2008) 95.

[21] E. Dadebo, Ethiop. J. Biol. Sci., 8 (2009)15.

[22] B.A. Shinkafi, L.A. ,Argungu and H.S. Akanbi, Nigerian Journal of Basic and Applied Science, 18(2010) 304.

[23] M.R. Manon and M.D. Hossain, J. Sci. Foundation, 9 (2011) 163.

[24] B.P.S. Kanwal and S.S. Pathani, International Journal of Food and Nutrition Science, 1 (2012)16.

[25] R. Omondi, A.W. Yasindi, and A. M. Magana, Journal of Ecology and the Natural Environment, 5 (2013) 224.

[26] J. Sharma, A. Parashar and R.K. Garg, Journal of chemical, Biological and Physical Sciences, 3 (2013) 2828.

[27] G. V. Nikolski, Ecology of Fishes. Academic Press, London, 1963.

[28] S. M. Das and S. S. Pathani, Indian J. Anim. Sci., 48 (1978) 461.

[29] S. P. Badola and H. R. Singh, Proc. Indian Natn. Sci. Acad. B, 46 (1980) 58.

[30] Y. R. Malhotra, Indian. J. Fish., 14 (1967) 313.

[31] M. A. Jyoti and Y. R. Malhotra, Matsya, 1 (1975) 53.

[32] M. A. Jyoti, J. Inland Fish. Res. Soc. India, 8 (1976) 24. 